\title{
Production of Nitrilase by a Recombinant Escherichia coli in a Laboratory Scale Bioreactor
}

\author{
Deepak Jain ${ }^{1}$, Vachan Singh Meena ${ }^{1}$, Shubhangi Kaushik ${ }^{1}$, Ashwini Kamble ${ }^{1}$, Yusuf Chisti ${ }^{2}$ and U. C. Banerjee ${ }^{1 *}$ \\ ${ }^{1}$ Department of Pharmaceutical Technology (Biotechnology), National Institute of Pharmaceutical Education and Research, Sector-67, SAS Nagar - 160062, Punjab, \\ India
}

${ }^{2}$ School of Engineering, Massey University, Private Bag 11 222, Palmerston North, New Zealand

\begin{abstract}
Effects of medium $\mathrm{pH}$ (uncontrolled and controlled), aeration rate and agitation intensity on the production of biomass and nitrilase by a recombinant Escherichia coli in a stirred-tank bioreactor are reported. The recombinant bacterium expressed the nitrilase gene of Alcaligenes faecalis. The initial $\mathrm{pH}$ of the culture medium had a strong influence on the growth of biomass and enzyme production. In batch fermentation process the growth and enzyme production were maximized at $37^{\circ} \mathrm{C}$ with an initial medium $\mathrm{pH} 7.0$. The fermentation was influenced by oxygen transfer efficiency of the bioreactor and by the turbulence regimen. The optimal production conditions were an aeration rate of $0.4 \mathrm{vvm}$ and an agitation speed of $400 \mathrm{rpm}$. Higher values of agitation speed and aeration rate proved detrimental to both biomass production and nitrilase activity. Under optimal conditions, the final dry biomass concentration was $6.9 \mathrm{~g} / \mathrm{L}$ and the biomass specific enzyme activity was $58 \mathrm{U} / \mathrm{g}$ dry cells.
\end{abstract}

Keywords: Nitrilase; Mandelic acid; Mandelonitrile; Fermentation; Recombinant Escherichia coli; Alcaligenes faecalis

\section{Introduction}

The enzyme nitrilase (EC 3.5.5.1) catalyzes the hydrolysis of nitrile $(-\mathrm{CN})$ functional groups in various compounds to the corresponding carboxylic acids and ammonia [1,2]. Nitrilase-mediated biotransformations have been extensively reviewed in the literature [2-5]. The enantio- and regio-selectivity of nitrilases offer synthetic possibilities that are difficult to achieve by non-enzymatic catalysis [6]. Production of enantiomerically pure $(R)-(-)$-mandelic acid by nitrilase-catalyzed conversion of mandelonitrile is well known [710]. Immobilization of nitrilases in the form of cross linked enzyme aggregates (CLEAs) has been reported $[11,12]$.

Nitrilases from several microbial sources have been purified, characterized and used in biotransformations [2-5,10,13-15] and reports were also available for enhancing the production of nitrilases by optimizing the fermentation process parameters [6,16-18]. Titers of many other enzymes have been shown to be highly dependent on the fermentation conditions used in their production [19-21].

This work is focused on production of intracellular nitrilase in a recombinant Escherichia coli expressing the nitrilase gene of Alcaligenes faecalis [11]. Earlier studies have discussed the gene cloning of nitrilases of Pseudomonas putida [16] and Pseudomonas fluorescens[13]. The nitrilase gene of Rhodococcus rhodochrous has also been cloned and overexpressed in E. coli [14]. Cloning, production and properties of a highly thermostable and enantioselective nitrilase of an Alcaligenes sp. have been described in literature $[10,15]$. This paper mainly focused on the interaction of agitation and aeration in a laboratory scale bioreactor during the growth of $E$. coli for the production of nitrilase.

\section{Materials and Methods}

\section{Chemicals}

Mandelonitrile, L-rhamnose and polypropylene glycol were purchased from Sigma-Aldrich (St. Louis, MO, USA). Growth media components were obtained from Hi-media Inc. (Mumbai, India).

\section{Microorganism and cultivation conditions}

A recombinant E. coli JM109 expressing the nitrilase gene of Alcaligenes faecalis MTCC-126 [11] was used. The stock culture was maintained at $4^{\circ} \mathrm{C}$ on plates of Luria Bertani (LB) agar supplemented with ampicillin $(100 \mu \mathrm{g} / \mathrm{mL})$. A loopfull of the microorganism from the stock culture was used to aseptically inoculate $50 \mathrm{~mL}$ of LB broth (supplemented with $100 \mu \mathrm{g} / \mathrm{mL}$ of ampicillin) in a $250 \mathrm{~mL}$ shake flask [17]. After $16 \mathrm{~h}\left(37^{\circ} \mathrm{C}, 200 \mathrm{rpm}\right)$, the above culture $(50 \mathrm{~mL})$ was used to inoculate $500 \mathrm{~mL}$ of $\mathrm{LB}$ broth (supplemented with $100 \mu \mathrm{g} / \mathrm{mL}$ ampicillin). In the second stage of inoculum preparation, L-rhamnose $(2 \mathrm{~g} / \mathrm{L})$ was added as an inducer after $4 \mathrm{~h}$ of incubation of the inoculum.

The above preculture $(500 \mathrm{~mL})$ was used to inoculate $5 \mathrm{~L}$ of LB broth (supplemented with $2 \mathrm{~g} / \mathrm{L}$ of L-rhamnose and $100 \mu \mathrm{g} / \mathrm{mL}$ of ampicillin) in a 7 L stirred fermenter (BIOFLO 3000; New Brunswick Scientific, Edison, NJ, USA). The fermenter was equipped with sensors for $\mathrm{pH}$ (Metteler-Toledo, MA, USA), dissolved oxygen (Ingold, Leicester, UK) and temperature. Fermentations were carried out as batches at $37^{\circ} \mathrm{C}$. Foam was controlled by manual addition of a polypropylene glycol antifoam agent when required. The bacterial growth and nitrilase production were determined in fermentations carried out at various initial $\mathrm{pH}$ values $(\mathrm{pH} 6.0,6.5,7.0,7.5$ and 8.0) and at controlled $\mathrm{pH}$ values ( $\mathrm{pH} 6.0,6.5,7.0$ and 7.5$)$. Various agitation speeds $(200,300,400$, $500 \mathrm{rpm})$ and aeration rates $(0.2,0.4,0.6 \mathrm{vvm})$ were tested in different fermentations. In the fermentations carried out at a controlled $\mathrm{pH}$, the $\mathrm{pH}$ was controlled by automatic addition of $1 \mathrm{~N} \mathrm{H}_{2} \mathrm{SO}_{4}$ and $1 \mathrm{~N} \mathrm{NaOH}$.

*Corresponding author: U. C. Banerjee, Department of Pharmaceutical Technology (Biotechnology), National Institute of Pharmaceutical Education and Research, Sector-67, SAS Nagar - 160062, Punjab, India, Tel: +91-172-221468287; Fax: +91-172-2214692; E-mail: ucbanerjee@niper.ac.in

Received January 24, 2012; Accepted February 25, 2012; Published February 27, 2012

Citation: Jain D, Meena VS, Kaushik S, Kamble A, Chisti Y et al. (2012) Production of Nitrilase by a Recombinant Escherichia coli in a Laboratory Scale Bioreactor. Ferment Technol 1:103. doi:10.4172/2167-7972.1000103

Copyright: (c) 2012 Jain D, et al. This is an open-access article distributed under the terms of the Creative Commons Attribution License, which permits unrestricted use, distribution, and reproduction in any medium, provided the original author and source are credited. 
The fermentations were sampled periodically for measurements of the biomass concentration and the nitrilase activity.

\section{Biomass concentration}

The biomass concentration was estimated by measuring the optical density (OD) of the sample at $600 \mathrm{~nm}$ using a spectrophotometer (Beckman DU 7400, USA) against a blank of the fresh medium. A standard curve was used to convert the optical density measurements to a dry cell weight (DCW). The standard curve had been made by measuring the optical density of various dilutions of a sample of the broth with a known DCW concentration. The latter had been determined by recovering the cells by centrifugation $(10,000 \mathrm{~g})$, washing twice with distilled water, overnight drying $\left(100^{\circ} \mathrm{C}\right)$ and weighing.

\section{Nitrilase activity assay}

Washed fresh cells (10 mg wet cell paste) were suspended in $2 \mathrm{~mL}$ of phosphate buffer (100 mM, pH 7.5) and mandelonitrile (5 mM) was added. The reaction mixture was incubated in a water bath at $37^{\circ} \mathrm{C}$ for $20 \mathrm{~min}$. The amount of ammonia produced by the enzymatic reaction was estimated by a fluorimetric method [17,22]. One unit of nitrilase activity was defined as the amount of enzyme required to produce $1 \mu \mathrm{mol}$ of ammonia per minute under the assay conditions.

\section{Volumetric oxygen transfer coefficient}

Volumetric oxygen transfer coefficient $\left(K_{L} a\right)$ for the stirred tank bioreactor was determined by the dynamic method [20]. Thus, the air flow to the bioreactor was stopped briefly and the decline in the concentration of dissolved oxygen (DO) because of consumption by the bacterium was recorded. The air flow then resumed at a preset rate and the consequent increase in DO concentration with time was recorded. The oxygen uptake rate $Q$ was calculated as the slope of the DO profile during the period of suspended aeration. The DO concentration profile recorded after the resumption of aeration was used to calculate the $K_{L} a$ [20]; thus:

$$
\mathrm{C}_{\mathrm{L}}=\mathrm{C}^{*}-\frac{1}{\mathrm{~K}_{\mathrm{L}} \mathrm{a}}\left(\frac{\mathrm{dC}_{\mathrm{L}}}{\mathrm{dt}}+\mathrm{Q}\right)
$$

Where $C^{\star}$ is the saturation concentration of dissolved oxygen and $C_{L}$ is the dissolved oxygen concentration at time any time $t$. A plot of the measured concentration $C_{L}$ versus $\left[\left(d C_{L} / d t\right)+Q\right]$ gave a straight line with a slope of $1 / K_{L} a$.

\section{Results and Discussion}

\section{Nitrilase production}

Effect of initial and controlled $\mathbf{p H}$ : The effect of initial $\mathrm{pH}$ in fermentations carried out without subsequent control of $\mathrm{pH}$ was examined at a controlled temperature of $37^{\circ} \mathrm{C}$. The aeration rate and the agitation speed were held constant at $0.4 \mathrm{vvm}$ and $400 \mathrm{rpm}$, respectively. In different fermentations, the initial $\mathrm{pH}$ values were 6.0, $6.5,7.0,7.5$ and 8.0. The value of the maximum specific growth rate was highest at $0.17 \mathrm{~h}^{-1}$ in the fermentation with an initial $\mathrm{pH}$ of 7.0 (Table 1). This initial $\mathrm{pH}$ also gave a substantially higher concentration of the biomass compared to the fermentations conducted at higher or lower values of the initial $\mathrm{pH}$.

To better understand the effect of $\mathrm{pH}$ on this fermentation, further experiments were carried out at various controlled $\mathrm{pH}$ values. The aeration rate, the agitation speed and the fermentation temperature remained fixed at $0.4 \mathrm{vvm}, 400 \mathrm{rpm}$ and $37^{\circ} \mathrm{C}$, respectively. The results are shown in Table 2. Among the fermentations carried out at various controlled $\mathrm{pH}$ values, the fermentation at a controlled $\mathrm{pH}$ of 7.0 was clearly the best in terms of the biomass concentration produced and the maximum specific growth rate attained (Table 2); however, the biomass specific nitrilase activity was only about $60 \%$ of the value obtained in the fermentation conduced at an uncontrolled initial $\mathrm{pH}$ of 7 (Table 1). Therefore, an initial $\mathrm{pH}$ of 7 without subsequent control was superior to a $\mathrm{pH}$-controlled fermentation in providing a highly active biocatalyst. In addition, the time to attain the maximum biomass specific enzyme activity was shorter in the fermentation without $\mathrm{pH}$ control (data not shown). In production of a recombinant nitrilase of Alcaligenes sp. in E. coli, [18] also reported a higher biomass specific enzyme activity in cells grown without $\mathrm{pH}$ control at an initial $\mathrm{pH}$ of 7.

Effect of agitation: Agitation rate is known to affect growth and enzyme production of some nitrilase producing bacteria [23]. Recombinant microorganisms can be particularly sensitive to the agitation regimen in a bioreactor [24]. Therefore, the effect of impeller agitation speed on nitrilase production was examined. The recombinant E. coli was grown at different agitation rates $(200-500 \mathrm{rpm})$ and $37^{\circ} \mathrm{C}$ in different batch fermentations. The aeration rate was always $0.4 \mathrm{vvm}$. The initial pH was 7.0 and was not controlled. The results are shown in Table 3. The maximum final biomass concentration and the biomass specific nitrilase activity were obtained when the cells were grown at $400 \mathrm{rpm}$ (Table 3 ). Lower values of agitation intensity adversely affected the final biomass concentration and nitrilase activity possibly because the oxygen transfer rate was reduced by reduced aeration. An agitation intensity of $>400 \mathrm{rpm}$ also reduced the final biomass concentration and the enzyme activity (Table 3 ). This may have been because of the effects of shear stress on the cells $[19,24]$.

In view of the possible effects of oxygen transfer on biomass and enzyme production, the values of the overall volumetric gas-liquid mass transfer coefficient $\left(K_{L} a\right)$ were measured at different agitation rates (Table 3 ). The $K_{L} a$, or the aeration capacity of the bioreactor,

\begin{tabular}{|l|l|l|l|}
\hline Initial $\mathrm{pH}$ & $\begin{array}{l}\text { Maximum biomass } \\
\text { concentration } \\
(\mathrm{mg} / \mathrm{mL})\end{array}$ & $\begin{array}{l}\text { Maximum nitrilase } \\
\text { activity } \\
(\mu \mathrm{mol} / \mathrm{min} \cdot \mathrm{mg} \text { dry cells })\end{array}$ & $\begin{array}{l}\text { Specific growth rate } \\
\left(\mathrm{h}^{-1}\right)\end{array}$ \\
\hline 6.0 & 4.33 & 0.045 & 0.07 \\
\hline 6.5 & 4.90 & 0.051 & 0.10 \\
\hline 7.0 & 6.92 & 0.058 & 0.17 \\
\hline 7.5 & 6.10 & 0.049 & 0.10 \\
\hline 8.0 & 5.05 & 0.047 & 0.07 \\
\hline
\end{tabular}

aThe agitation speed and aeration rate were constant at $400 \mathrm{rpm}$ and $0.4 \mathrm{vvm}$ respectively. All the experiments were carried out in triplicate and the average value was taken.

Table 1: Effect of initial pH on final biomass concentration, the specific growth rate and the final nitrilase activity ${ }^{a}$

\begin{tabular}{|l|l|l|l|}
\hline $\mathrm{pH}$ & $\begin{array}{l}\text { Maximum biomass } \\
\text { concentration } \\
(\mathrm{mg} / \mathrm{mL})\end{array}$ & $\begin{array}{l}\text { Maximum nitrilase activity } \\
(\mu \mathrm{mol} / \mathrm{min} \cdot \mathrm{mg} \text { dry cells })\end{array}$ & Specific growth rate $\left(\mathrm{h}^{-1}\right)$ \\
\hline 6.0 & 3.03 & 0.040 & 0.06 \\
\hline 6.5 & 2.99 & 0.052 & 0.13 \\
\hline 7.0 & 5.01 & 0.035 & 0.19 \\
\hline 7.5 & 3.86 & 0.045 & 0.08 \\
\hline
\end{tabular}

aThe agitation speed and aeration ratewere constant at $400 \mathrm{rpm}$ and $0.4 \mathrm{vvm}$ respectively. All the experiments were carried out in triplicate and the average value was taken.

Table 2: Effect of controlled $\mathrm{pH}$ on final biomass concentration, the specific growth rate and the final nitrilase activity ${ }^{a}$ 
Citation: Jain D, Meena VS, Kaushik S, Kamble A, Chisti Y et al. (2012) Production of Nitrilase by a Recombinant Escherichia coli in a Laboratory Scale Bioreactor. Ferment Technol 1:103. doi:10.4172/2167-7972.1000103

was the highest at $500 \mathrm{rpm}$ (Table 3 ) and was progressively reduced by a reduction in the agitation speed (Table 3). Clearly, therefore, oxygen limitation could not explain the reduced growth and nitrilase production seen at the agitation speed of $500 \mathrm{rpm}$ (Table 3). The concentration of extracellular protein and the fermentation $\mathrm{pH}$ were not affected by increasing the agitation speed to $500 \mathrm{rpm}$ relative to the results at $400 \mathrm{rpm}$ (data not shown). Therefore, an increased agitation did not physically damage the cells, but affected growth and enzyme production via some of the other shear-dependent mechanisms that have been described [24].

Effect of aeration: In view of the aforementioned effects of oxygen transfer on cell growth and enzyme production, the effect of changes in aeration rate on the fermentation was investigated. The agitation speed was fixed at $400 \mathrm{rpm}$. The initial $\mathrm{pH}$ was set at 7.0 without subsequent control. The other fermentation conditions were as previously specified. Only the aeration rate varied in different batch fermentations. The aeration rate values of $0.2,0.4$ and $0.6 \mathrm{vvm}$ were examined. The data are shown in Table 4. Clearly, the oxygen transfer capacity of the bioreactor (i.e. the $K_{L} a$ ) progressively increased with increasing aeration rate (Table 4 ). The optimal aeration rate was 0.4 vvm. Increasing the aeration rate above $0.4 \mathrm{vvm}$ had a negative effect on both the final biomass concentration and the biomass specific nitrilase activity (Table 4). The most probable reason may be that at higher aeration rate, air flow along the shaft increased and impeller started flooding. An impeller when surrounded by air column is no longer in good contact with liquid and results in meager mixing, reduced air dispersion with less oxygen transfer efficiency. Increased aeration rate seems to be reducing the growth lag as well as time to achieve the maximum growth at a constant agitation rate. The less enzyme activity at higher aeration rate may be due to the oxygen toxicity. Oxygen is vital for the growth of the aerobic organism, however, at higher aeration rate, enzyme activity may be adversely affected. This fermentation therefore required a relatively high oxygen transfer capability in the bioreactor, but not an excessively intense hydrodynamic shear environment [23].

\section{Conclusion}

A recombinant E.coli was used to produce the nitrilase of

\begin{tabular}{|l|l|l|l|l|}
\hline $\begin{array}{l}\text { Agitation speed } \\
(\mathrm{rpm})\end{array}$ & $\begin{array}{l}\text { Maximum } \\
\text { biomass } \\
\text { concentration } \\
(\mathrm{mg} / \mathrm{mL})\end{array}$ & $\begin{array}{l}\text { Maximum nitrilase } \\
\text { activity } \\
(\mu \mathrm{mol} / \mathrm{min} \cdot \mathrm{mg} \text { dry cells })\end{array}$ & $\mathrm{K}_{\mathrm{L}} \mathrm{a}\left(\mathrm{h}^{-1}\right)$ & $\begin{array}{l}\text { Specific } \\
\text { growth rate } \\
\left(\mathrm{h}^{-1}\right)\end{array}$ \\
\hline 200 & 4.02 & 0.038 & 58 & 0.08 \\
\hline 300 & 5.42 & 0.048 & 81 & 0.14 \\
\hline 400 & 6.92 & 0.057 & 100 & 0.17 \\
\hline 500 & 6.31 & 0.046 & 120 & 0.13 \\
\hline
\end{tabular}

${ }^{a}$ The aeration rate remained constant at $0.4 \mathrm{vvm}$. All the experiments were carried out in triplicate and the average value was taken.

Table 3: Effect of agitation speed on final biomass concentration, the specific growth rate, $K_{L} a$ and the final nitrilase activity ${ }^{a}$

\begin{tabular}{|l|l|l|l|l|}
\hline $\begin{array}{l}\text { Aeration rate } \\
(\mathrm{vvm})\end{array}$ & $\begin{array}{l}\text { Maximum } \\
\text { biomass } \\
\text { concentration } \\
(\mathrm{mg} / \mathrm{mL})\end{array}$ & $\begin{array}{l}\text { Maximum nitrilase } \\
\text { activity } \\
(\mu \mathrm{mol} / \mathrm{min} \cdot \mathrm{mg} \text { dry } \\
\text { cells })\end{array}$ & $K_{L} a\left(\mathrm{~h}^{-1}\right)$ & $\begin{array}{l}\text { Specific } \\
\text { growth rate } \\
\left(\mathrm{h}^{-1}\right)\end{array}$ \\
\hline 0.2 & 5.92 & 0.051 & 80 & 0.13 \\
\hline 0.4 & 6.92 & 0.058 & 100 & 0.17 \\
\hline 0.6 & 6.30 & 0.050 & 123 & 0.11 \\
\hline
\end{tabular}

aThe agitation speed remained constant at $400 \mathrm{rpm}$. All the experiments were carried out in triplicate and the average value was taken.

Table 4: Effect of aeration rate on final biomass concentration, the specific growth rate, $K_{L} a$ and the final nitrilase activity ${ }^{a}$
Alcaligenes faecalis MTCC-126 as an intracellular enzyme. Whole cells of the recombinant bacterium were potently effective as a biocatalyst for the biotransformation of mandelonitrile to mandelic acid (data not shown). In batch fermentation, the optimal conditions for producing a high concentration of the cells with a high biomass specific nitrilase activity were an initial $\mathrm{pH}$ of 7.0 without control; a temperature of $37^{\circ} \mathrm{C}$; an aeration rate of $0.4 \mathrm{vvm}$; and an agitation speed of $400 \mathrm{rpm}$. The recombinant $E$. coli cells biotransformed mandelonitrile to $(R)-(-$ )- mandelic acid with remarkable stereoselectivity.

\section{Acknowledgement}

Authors gratefully acknowledge the financial assistance provided by DBT and CSIR, Government of India, to carry out this study.

\section{References}

1. Banerjee A, Sharma R, Banerjee UC (2002) The nitrile-degrading enzymes: current status and future prospects. Appl Microbiol Biotechnol 60: 33-44

2. Thuku RN, Brady D, Benedik MJ, Sewell BT (2009) Microbial nitrilases: versatile, spiral forming, industrial enzymes. J Appl Microbiol 106: 703-727.

3. O'Reilly C, Turner PD (2003) The nitrilase family of CN hydrolysing enzymes-a comparative study. J Appl Microbiol 95: 1161-1174.

4. Martínková L, Vejvoda V, Kaplan O, Dubáč D, Malandra A, et al. (2009) Fungal nitrilases as biocatalysts: Recent developments. Biotechnol Adv 27: 661-670.

5. Martínková L, Křen V (2010) Biotransformations with nitrilases. Curr Opin Chem Biol 14: 130-137

6. Naik SC, Kaul P, Barse B, Banerjee A, Banerjee UC (2008) Studies on the production of enantioselective nitrilase in a stirred tank bioreactor by Pseudomonas putida MTCC 5110. Bioresour Technol 99: 26-31.

7. Banerjee A, Kaul P, Banerjee UC (2006) Enhancing the catalytic potential of nitrilase from Pseudomonas putida for stereoselective nitrile hydrolysis. Appl Microbiol Biotechnol 72: 77-87

8. Ress-Loschke M, Friedrich T, Hauer B, Mattes R, Engels D (2005) Method for producing chiral carboxylic acids from nitriles with the assistance of a nitrilase or microorganisms which contain a gene for the nitrilase. US Patent 6869783 B1.

9. Xue YP, Xu SZ, Liu ZQ, Zheng YG, Shen YC (2011) Enantioselective biocatalytic hydrolysis of $(R, S)$-mandelonitrile for production of $(R)-(-)$-mandelic acid by a newly isolated mutant strain. J Ind Microbial Biotechnol 38: 337-345.

10. Zhang ZJ, Xu JH, He YC, Ouyang LM, Liu YY, et al. (2010) Efficient production of $(R)-(-)$-mandelic acid with highly substrate/product tolerant and enantioselective nitrilase of recombinant Alcaligenes sp. Process Biochem 45: 887-891.

11. Kaul P (2007) Reaction engineering aspects of nitrilase from Alcaligenes faecalis MTCC 126. PhD thesis, Department of Pharmaceutical Technology (Biotechnology), National Institute of Pharmeceutical Education and Research, SAS Nagar, India.

12. Kumar S, Mohan U, Kamble AL, Pawar S, Banerjee UC (2010) Cross linked enzyme aggregates of recombinant Pseudomonas putida nitrilase for enantioselective nitrile hydrolysis. Bioresour Technol 101: 6856-6858.

13. Kiziak C, Conradt D, Stolz A, Mattes R, Klein J (2005) Nitrilase from Pseudomonas fluorescens EBC191: Cloning and heterologous expression of the gene and biochemical characterization of the recombinant enzyme. Microbiology 151: 3639-3648.

14. Luo H, Fan L, Chang Y, Ma J, Yu H, et al. (2010) Gene cloning overexpression and characterization of the nitrilase from Rhodococcus rhodochrous tg1-A6 in E. coli. Appl Biochem Biotechnol 160: 393-400.

15. Zhang ZJ, Xu JH, He YC, Ouyang LM, Liu YY (2011) Cloning and biochemical properties of a highly thermostable and enantioselective nitrilase from Alcaligenes sp. ECU0401 and its potential for (R)-(-)-mandelic acid production. Bioprocess Biosyst Eng 34: 315-322.

16. Banerjee A, Dubey S, Kaul P, Barse B, Piotrowski M, et al. (2009) Enantioselective nitrilase from Pseudomonas putida: cloning, heterologous expression, and bioreactor studies. Mol Biotechnol 41: 35-41.

17. Dubey S, Singh A, Banerjee UC (2011) Response surface methodology of nitrilase production by recombinant Escherichia coli. Braz J Microbiol 42. 
Citation: Jain D, Meena VS, Kaushik S, Kamble A, Chisti Y et al. (2012) Production of Nitrilase by a Recombinant Escherichia coli in a Laboratory Scale Bioreactor. Ferment Technol 1:103. doi:10.4172/2167-7972.1000103

18. Liu JF, Zhang ZJ, Li AT, Pan J, Xu JH (2011) Significantly enhanced production of recombinant nitrilase by optimization of culture conditions and glycerol feeding. Appl Microbiol Biotechnol 89: 665-672.

19. Bhattacharyya MS, Singh A, Banerjee UC (2008) Production of carbonyl reductase by Geotrichum candidum in a laboratory scale bioreactor. Bioresour Technol 99: 8765-8770.

20. Singh A, Chisti Y, Banerjee UC (2011) Production of carbonyl reductase by Metschnikowia koreensis. Bioresour Technol 102: 10679-10685.

21. Soni P, Kansal H, Banerjee UC (2008) Optimization of process parameters for the production of carbonyl reductase by Candida viswanathii in a laboratoryscale fermenter. J Ind Microbiol Biotechnol 35: 167-173.
22. Banerjee A, Sharma R, Banerjee UC (2003) A rapid and sensitive fluorometric assay method for the determination of nitrilase activity. Biotechnol App Biochem 37: 289-293.

23. Kamble AL, Meena VS, Banerjee UC (2010) Effect of agitation and aeration on the production of nitrile hydratase by Rhodococcus erythropolis MTCC 1526 in a stirred tank reactor. Lett Appl Microbiol 51: 413-420.

24. Chisti Y (2010) Shear sensitivity. Flickinger MC In: Encyclopedia of Industria Biotechnology, Bioprocess, Bioseparation, and Cell Technology, Wiley, New York, 7: 4360-4398. 